\title{
The Problem of Transportation Infrastructure Development in Papua Region Indonesia
}

\author{
R. Didin Kusdian ${ }^{1}$ \\ ${ }^{1}$ Civil Engineering Post Graduate Program, Sangga Buana University, Bandung, Indonesia \\ Correspondence: R. Didin Kusdian, Civil Engineering Post Graduate Program, Sangga Buana University, \\ Bandung, Indonesia. E-mail: r.didin@usbypkp.ac.id
}

Received: February 12, 2018

Accepted: May 17, 2018 Online Published: September 28, 2018

doi:10.5539/jsd.v11n5p277

URL: https://doi.org/10.5539/jsd.v11n5p277

\begin{abstract}
The eastern region of Indonesia, Papua, decentralized government administration has been divided into 2 (two) provinces, namely West Papua Province with provincial capital of Manokwari and Papua Province with provincial capital of Jayapura. Judging from the history of all the existing provinces, the last territory of independence becomes part of the territory of the Unitary State of the Republic of Indonesia. The Republic of Indonesia was established in 1945, and this easternmost region entered as part of the territory of the Republic of Indonesia in 1962. The number and density of its population are the fewest. The development of this area continues to be carried out, various concepts of development planning continue to be developed and implemented. Progress was achieved in several aspects of community life. However, the results achieved have not been as expected. The infrastructure network that has been built has not been successful in balancing the issues of inequality and equity in the context of the whole of Indonesia as a unified infrastructure system that supports all sectors of the lives of citizens, especially the economic and social sectors. Infrastructure is meant here is the infrastructure that is the responsibility of the government in the ministry of communications and the ministry of public works and public housing.

Constraints of topographic conditions, rare population, cultural perceptions, and distance coverage of the already advanced areas are issues that need to be addressed and solved alternative solutions. The system constraints of all infrastructure and the priority of which components must be built first and the priority of the location also become individual issues, which in this system will also include power supply system, fuel, and cement as the main material of infrastructure building.

This paper summarizes and discusses some of the results of discussions and studies related to the acceleration of infrastructure development in Papua.
\end{abstract}

Keywords: population, land condition, infrastructure system, acceleration, cultural perception

\section{Introduction}

From the period of government to the next government period over the last forty years, the acceleration of the development of western irian or irian jaya which is currently the prpvinsi of West Papua and Papua continues to generate new ideas in the concept of acceleration of development of the region that challenge more difficult than the territory of the Republic of Indonesia others.

Ideas and concepts on the acceleration of development of the Papua and West Papua region are still few that are written in the path of academic articles. This paper is intended to open the way for academic discussion globally on the acceleration of the development of infrastructure system network in Papua and West Papua.

In the Map of Potential of Cultivation, planned locations and boundaries of Production Forest, Fishery, Plantation, Livestock, Wetland, Dryland and Transmigration.

Transmigration Area in Cultivation map is located around Jayapura, Fakf-fak and Merauke.

Road network planning includes connectivity between Papua, West Papua, including the linkages between cities on the north coast, intercity towns on the north coast and central mountains, and between the two with southern Papua.

The first line, the northern coastal cities include the connectedness of a series of cities of Sorong, Manokwari, 
Nabire, Yapen-Waropen to Jayapura. Where between Manokwari and Nabire there is a branch segment that connects to Fak-fak.

The Second Line, the central mountainous region is connected by land routes from Nabire, Puncak Jaya, Mulia, Wamena, Jayapura. With branches from Puncak Jaya to Timika.

The third line, is the longitudinal road from north to south parallel to the border line with the state of Papua New Guinea from Jayapura to Merauke.

The first, second and third lanes are connected to form a network. The problem of road construction in connecting areas along the southern coast between Timika-Agats-Merauke is the confluence of rivers. In this area the development of river transportation becomes an important thing.

Over the past forty years on existing facts, the overland road network in the region has been slowly developing its implementation, due to various difficulties, including topographical issues, materials and tools to be imported, and human resources. So that the accessibility and mobility in the dominance of air transportation that is limited tonnage and expensive transportation.

Therefore, it is necessary to continuously study the development acceleration strategy comprehensively, covering many sectors. The hope is that the West Papua and Papua provinces can align the level of development, economic growth, and the welfare of its citizens with other regions in Indonesia in a fair and equitable way.

\section{Population}

The human population has always been the target of development. Each development aims to improve the welfare and quality of life of human beings who become residents of the built area. Population data are the main important data in the analysis of development planning.

The Papuan population figures show the comparison of Java and Indonesia as a whole, as well as with neighboring Papua, Papua New Guinea, Australia and the Philippines (See Table 1).

Papua is the largest island in the territory of the Republic of Indonesia, but the population is the least. The table shows the comparison of the population of Papua with 6 (six) provinces located in Java, namely the Special Capital Region of Jakarta, Banten, West Java, Central Java, Yogyakarta Special Region, and East Java. The number of Papuans is roughly the same as the population of Yogyakarta, whose area is much narrower.

The least population can also be an obstacle to the lack of speed of development, because of the difficulty of getting human resources, labor, to carry out the implementation of development. From the framework of preparing a feasibility study to get approval of the use of development funds, the small population will make it difficult. Because and hard to get because the return from the population as a user or consumer, a little. The economic feasibility of a project is difficult to achieve economically viable, let alone financially. Public infrastructure projects require the use of substantial funds, while utilization in small population areas, the flow of small incoming funds. Benefit cost ratio so small. It takes attention to apply a specific framework in the process and eligibility criteria for the use of funds for the acceleration of development of Papua. 
Table 1. Population of Papua compare with Java, whole Indonesia, and neighbour countries

\begin{tabular}{|c|c|c|c|c|c|}
\hline State/Country & Population & Ratio to Papua & & Area $\left(\mathbf{k m}^{2}\right)$ & $\begin{array}{l}\text { Density } \\
\left(\text { person/km } / \mathbf{k m}^{2}\right)\end{array}$ \\
\hline West Papua & 760.422 & $21 \%$ & & & 9 \\
\hline Papua & 2.833 .381 & $79 \%$ & & & 10 \\
\hline \multirow[t]{3}{*}{ sub total Papua } & 3.593.803 & & & $421.981,00$ & \\
\hline & & Ratio of Papua to & Ratio of each (row) & & \\
\hline & & Each (row) & to Papua & & \\
\hline Banten & 10.632 .166 & $33,80 \%$ & $295,85 \%$ & $9.662,92$ & 1237 \\
\hline Jakarta & 9.607 .787 & $37,41 \%$ & $37,41 \%$ & 664,00 & 15328 \\
\hline West Java & 43.053 .732 & $8,35 \%$ & $1198,00 \%$ & $43.177,00$ & 320 \\
\hline Middle Java & 32.382 .657 & $11,10 \%$ & $901,07 \%$ & $32.549,00$ & 1030 \\
\hline Yogyakarta & 3.457 .491 & $103,94 \%$ & $96,21 \%$ & $3.186,00$ & 1174 \\
\hline East Java & 37.476 .757 & $9,59 \%$ & $1042,82 \%$ & $47.923,00$ & 813 \\
\hline sub total java & 136.610 .590 & $2,63 \%$ & $3801,28 \%$ & & \\
\hline Indonesia & 237.641.326 & $1,51 \%$ & $6612,53 \%$ & $1.922 .570,00$ & 134 \\
\hline Papua New Guinea & 8.084 .999 & $44,45 \%$ & $224,97 \%$ & 462,84 & 15 \\
\hline Australia & 24.798 .700 & $14,49 \%$ & & $7.692,02$ & 3.2 \\
\hline Philipines & 100.981 .437 & $10,53 \%$ & & 343,45 & 294 \\
\hline
\end{tabular}

\section{Land Conditions}

Identified areas with no large and dominant groundwater in Papua, according to the groundwater potential map published by the provincial government of West Papua and Papua, in the middle and the head of birds, this groundless area has a river. The rest of the area has shallow groundwater and groundwater potential. See Figure 1. 


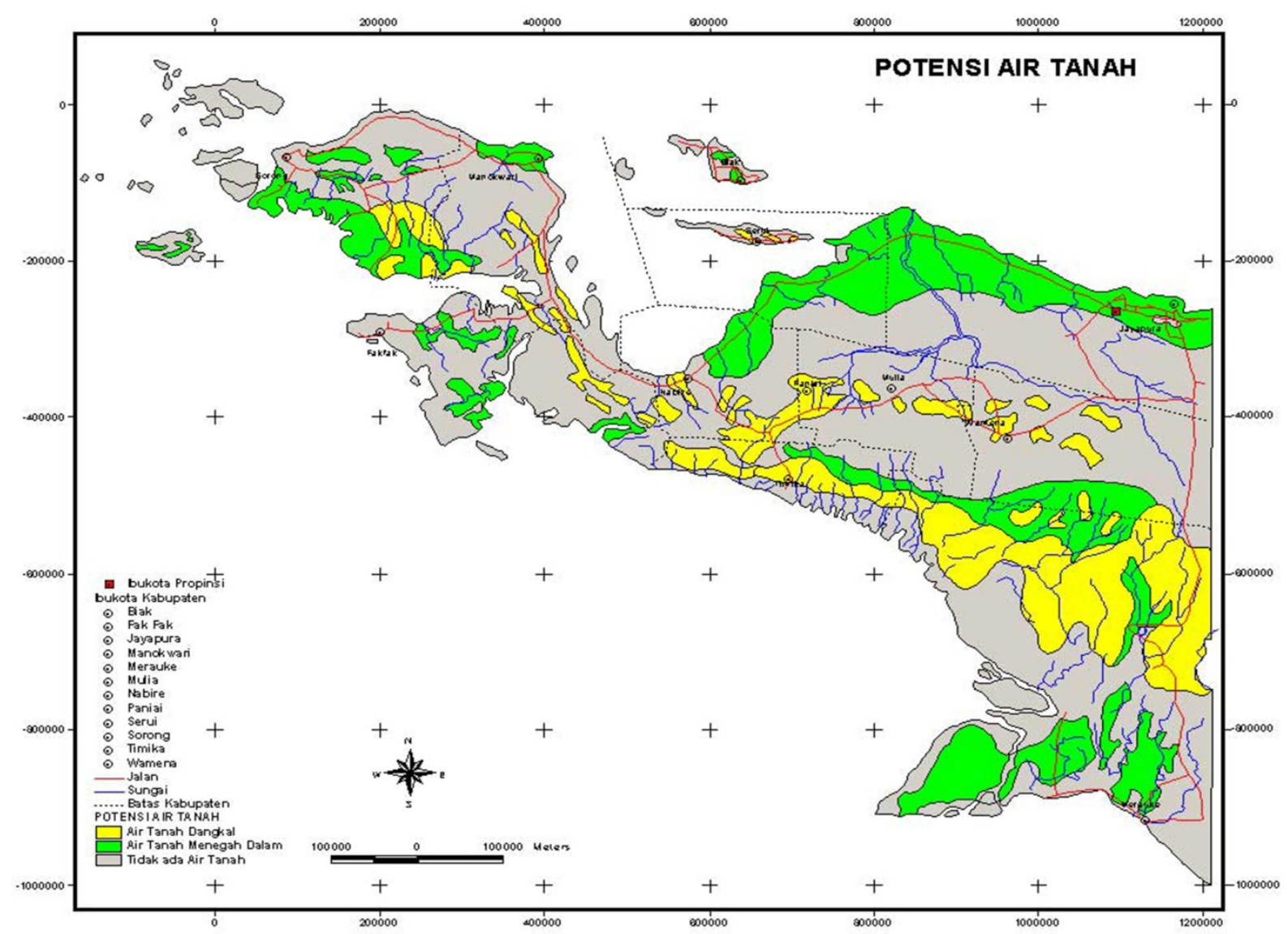

Figure 1. Ground water potential of Papua

Papua geological explanation provides information there are 4 (four) main groups namely: limestone or dolomite dominating the southern and central birds; frozen rocks in the central mountains, in the middle of the bird's head and the isup island near the bird's head. In West Papua (bird heads) south and on the north coast of Papua are loose sediments, gravel, sand, silt. The north coast and the middle of the bird's head, around Fak-Fak and the central region of Papua's mainland are formed from unified sediments.

The type of land that dominates Papua is latosol. Especially in the nothern and bird heads. The southern and part of the center consists of podsolic soil. Mediteran Rensia is located around Fak-Fak, south of Nabire and the center of the bird's head. See Figure 2. 


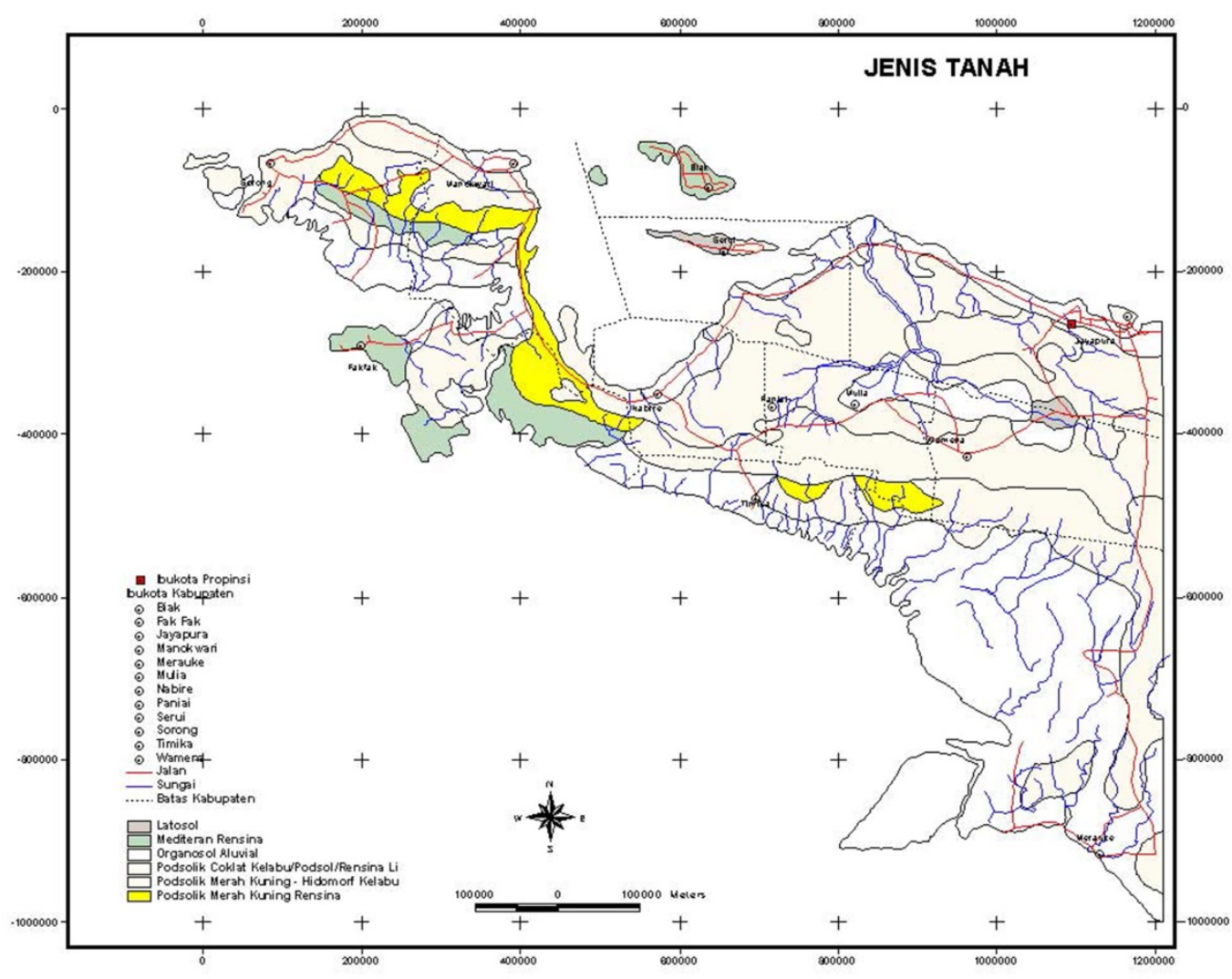

Figure 2. Type of soil of Papua

The biak island has the potential of ground water, with limestone geology, mediteran land of rensia, quite dominant hills and mountains.

The most widespread land use is dense forest / raw forest and fields. Swamps and lakes are in the southern, central and northern parts of the bird's head, including Lake Sentani near Jayapura. See Figure 3.

Papua region with a steep slope greater than $65 \%$ is wide and dominant; in the middle, north and bird heads. Other areas are generally hills. A flat area with a sloping slope of less than $3 \%$ especially on the south coast, which is wider than the north coast. See Figure 4 and 5. 


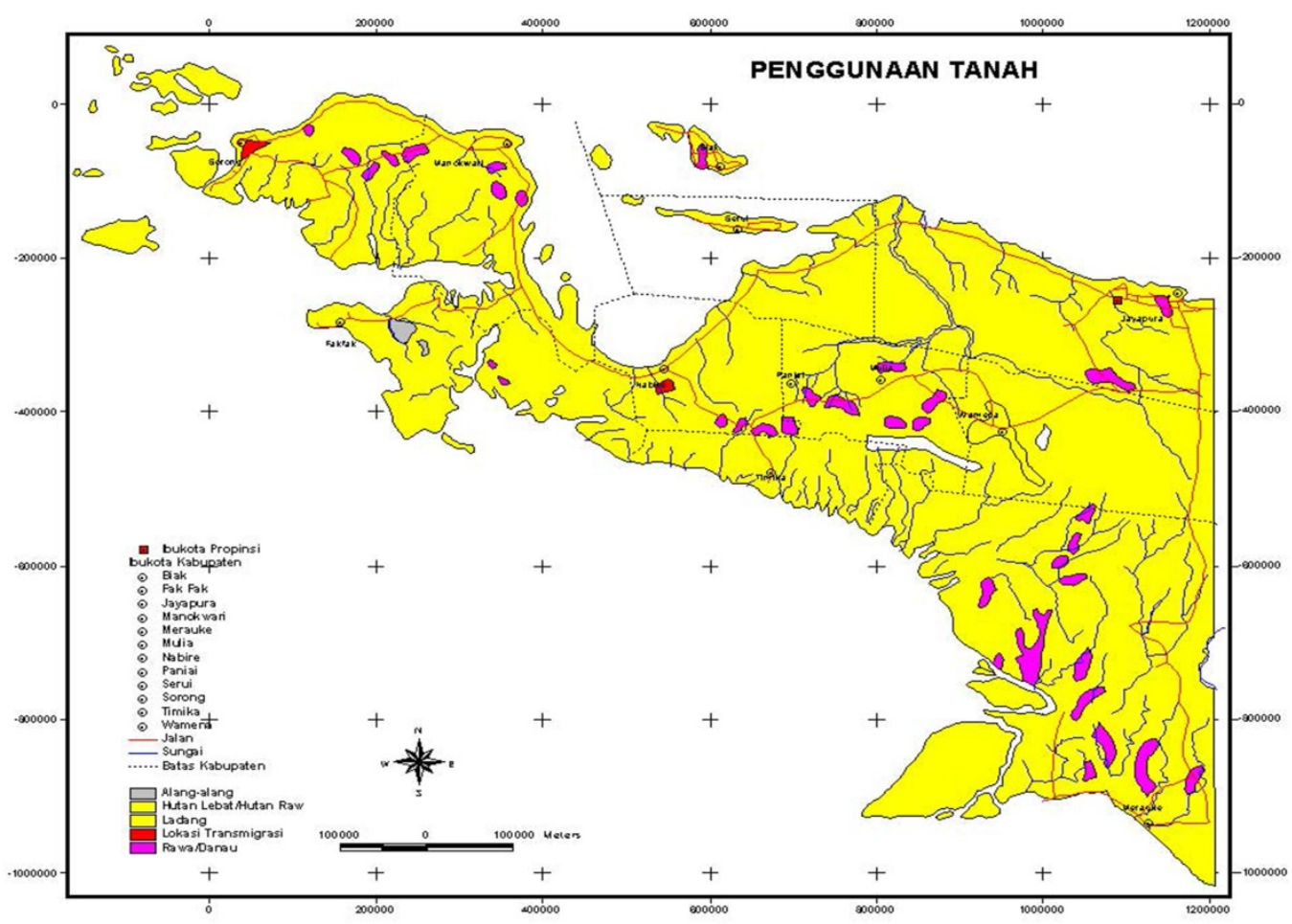

Figure 3. Land use of Papua

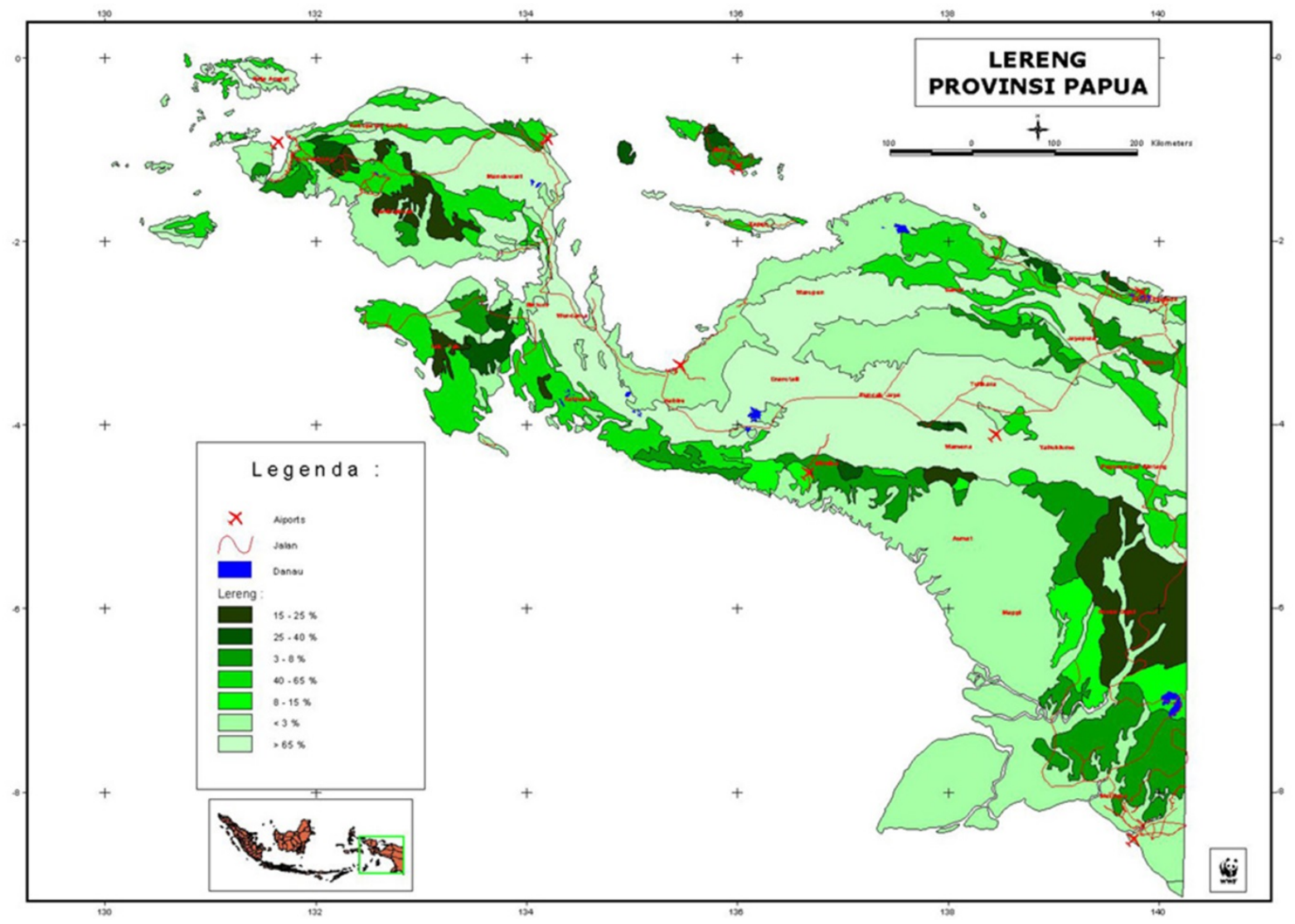

Figure 4. Slopes of Papua 


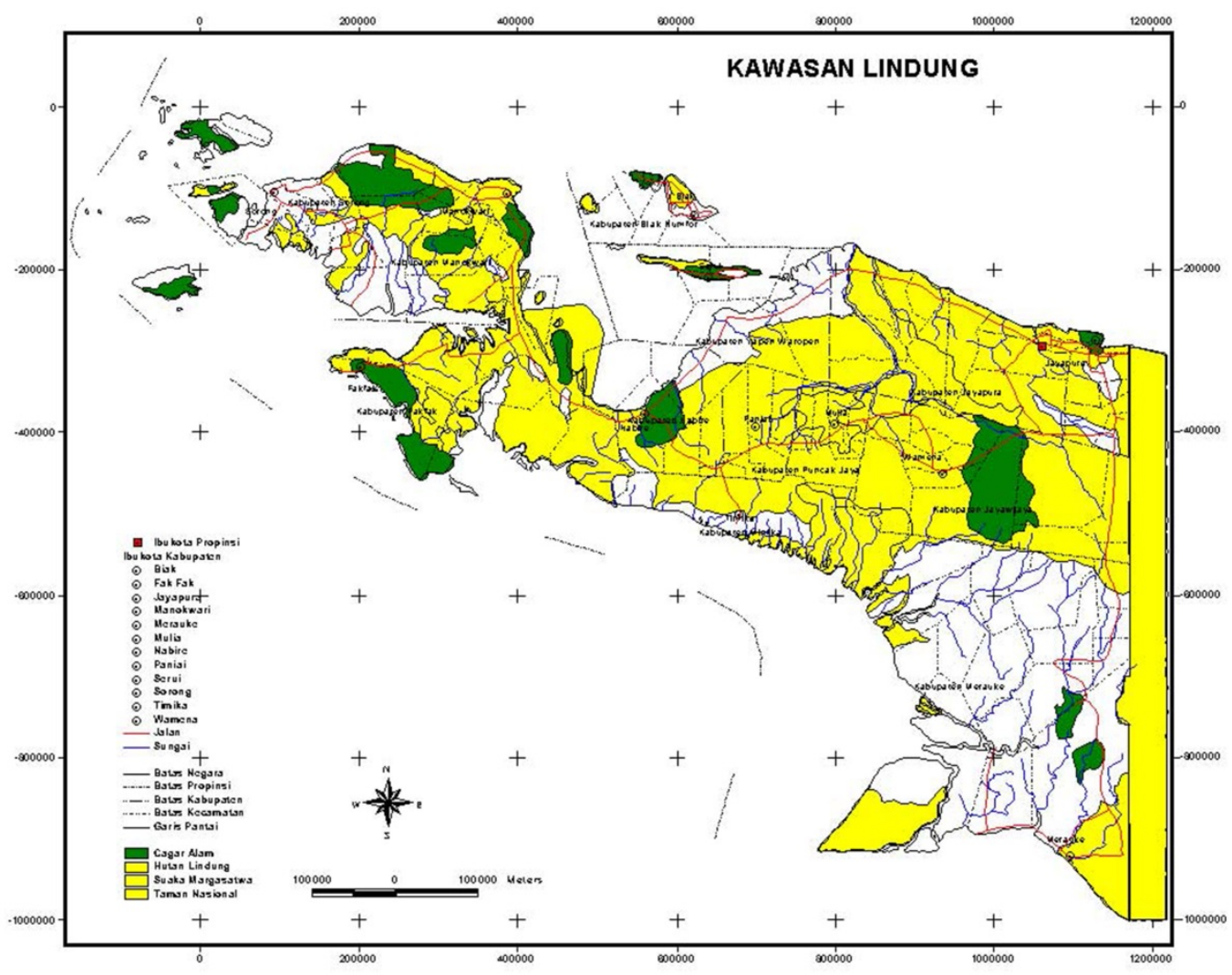

Figure 5. Proteced area of Papua

\section{Infrastructure System}

Until now the cities that succeeded in developing Papua is cities along the coastal region. Only a small percentage of the developing area is compared to the overall area of Papua. The unsolved problem to date is how to easily access other areas in the hilly and mountainous islands of Papua. Until now dependable still connect by air transportation which have limited capacity of goods transport and expensive.

Acceleration of development of land transportation network including river, is needed in accessing the region of Central Papua to accelerate development. It is therefore necessary to proceed more precisely which infrastructure priority should be built.

Some elements of infrastructure development activities that need attention are as follows:

- Construction of Cement Plant

- Development of Road Network

- Construction of Refinery and Oil Fuel Depot

- Construction of Ports and Coal Depots

- Construction of Power Station

- Development of Raw Water Supply System

- Development of Water Treatment, Mining and Distribution Systems

- Development of Water Treatment and Distribution System

- Industry

- Development of Telecommunication Network Systems, Telematics, Internet

- Papua in the 4th Industrial Revolutionary Era 
Construction of a cement plant should be prioritized as a major supporter of other infrastructure developments. Development in Papua by bringing in cement from outside Papua has been carried out over the past 5 (five) decades, and the results have been slow. With the availability of cement produced by Papua, the development can be accelerated by accelerating the construction of road network of automobiles (cars, bus, trucks) with rigid pavement type. Rigid pavement type roads would be suitable for Papua, as maintenance costs would be cheaper and less labor intensive, while the human resource factor in Papua is few. By building a rigid pavement road network with large tonnage capacity, trucking to all parts of Papua can be bigger in production than in the air today.

The mobility of land and industrial transportation needs to be quickly supported by the construction of refineries and fuel depots. After being built in coastal areas, in the future along with the development of road infrastructure and road traffic, the need for fuel oil needs to be supplemented quickly, such as by adding refineries and / or depots at several points in the central Papua's mainland.

With regard to water resources as the most important element in the way of life and development, of course from what has been existing now, developed in line with the development needs and acceleration needs that need to be anticipated before the acceleration of development in all sectors. A well-prepared water resources system includes the construction of a network of water supply systems, clean water, industrial water and drinking water.

The development of industry in Papua becomes a choice for the future, with the type of industries derived from Papua's natural potential. To support the industries need to be prepared also the development of power plants and power transmission network system. All types of power plants need to be developed in Papua. For diesel power plants other than refineries and oil fuel depots, it is necessary to prepare ports and coal depots. The possibility of geothermal power plants needs to be reviewed through studies in mountainous areas. The construction of dams and power plants in the form of turbine using potential energy of water, still requires a review of studies for rivers of Papua in mountains region.

After the industries is well established and productive, there is no need to wait long to follow the direct current, where later Papua industries need to be directly supported by telematics system equipment, in the form of telecommunication network and internet network infrastructure. So that Papua can directly participate as a player in the era of 4 th industrial revolution. Priority among development acceleration elements in Papua and West Papua, can be explained as shown in Figure 6.

\section{Transportation System to Exit and Log Papua}

In addition to the inland Papua mainland road transport system that is integrated into the other systems of infrastructure that have been discussed above, in order to exit and enter Papua, the relationship pattern can be viewed from the existing, historical, and island infrastructure side, and provincial governance. Let's say the entity consists of Biak, West Papua, Papua, Indonesia, International, and Papua New Guinea as a land-bound country (one island).

Biak has a special position, because it is an area that has historically been in contact with the international world since World War II. Infrastructure and culture have been advanced, compared to other regions in Papua and West Papua. Airfield Biak is a former US air base after being seized from Japan during World War II. From the long side of the runway, it still leaves a function that until now is utilized. The side of public relations with development and progress also provides a positive relationship with the acceleration of Papuan development as a whole.

West Papua is a new province resulting from the division of Papua from one province into two provinces. The territory of other provinces, in the case of the exit and entry of Papua, in this case is unified into Indonesia. Then other areas of the world that can not be reached by road, united into the International. While the territory of an island country that is bordered and can be reached by land, was raised specifically, that is Papua New Guinea.

With the mindset as above, the exit and entry into Papua region, can be described the pattern, and the need for acceleration of infrastructure development as in Figure 7. 


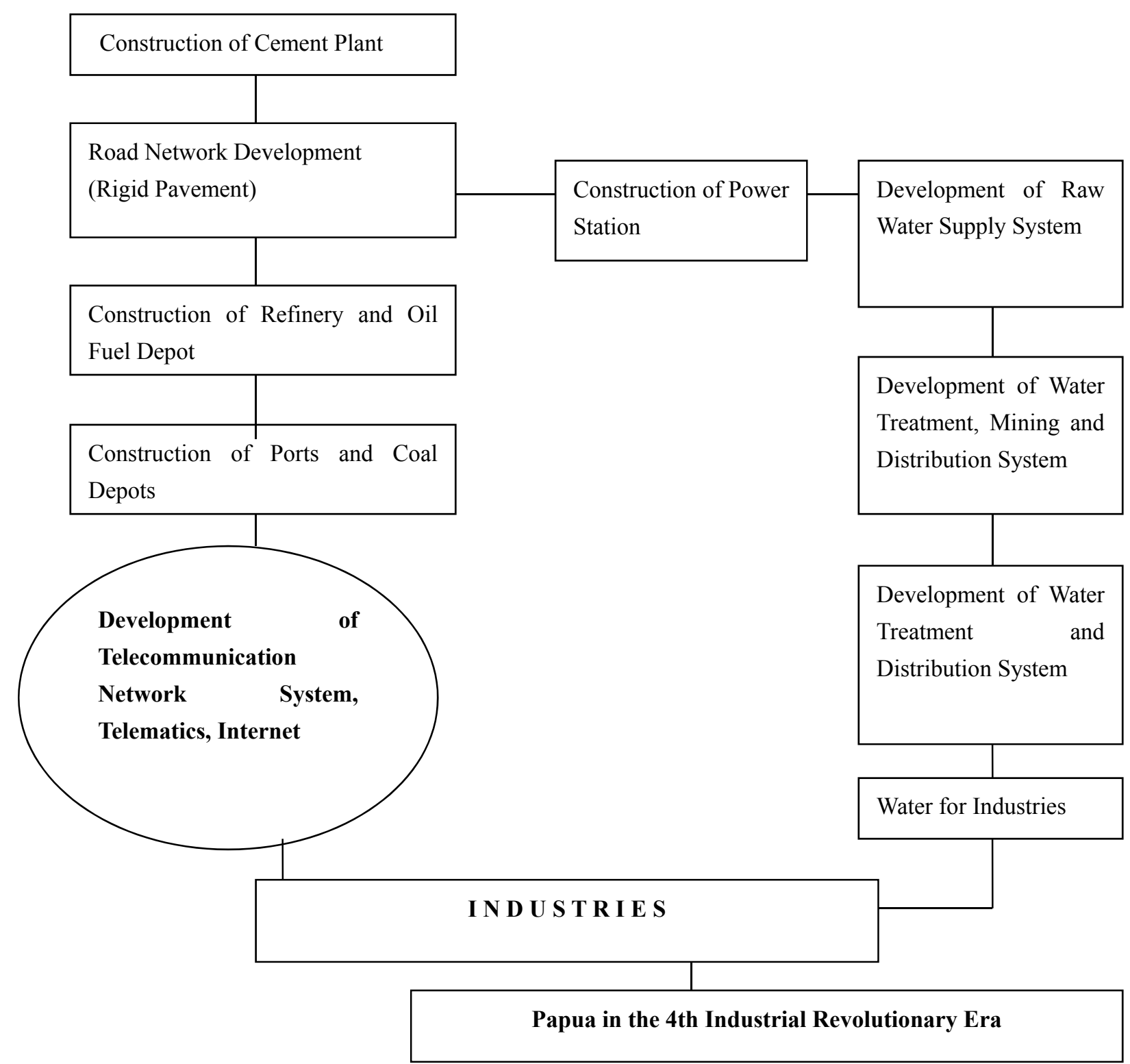

Figure 6. Papua priority development options 


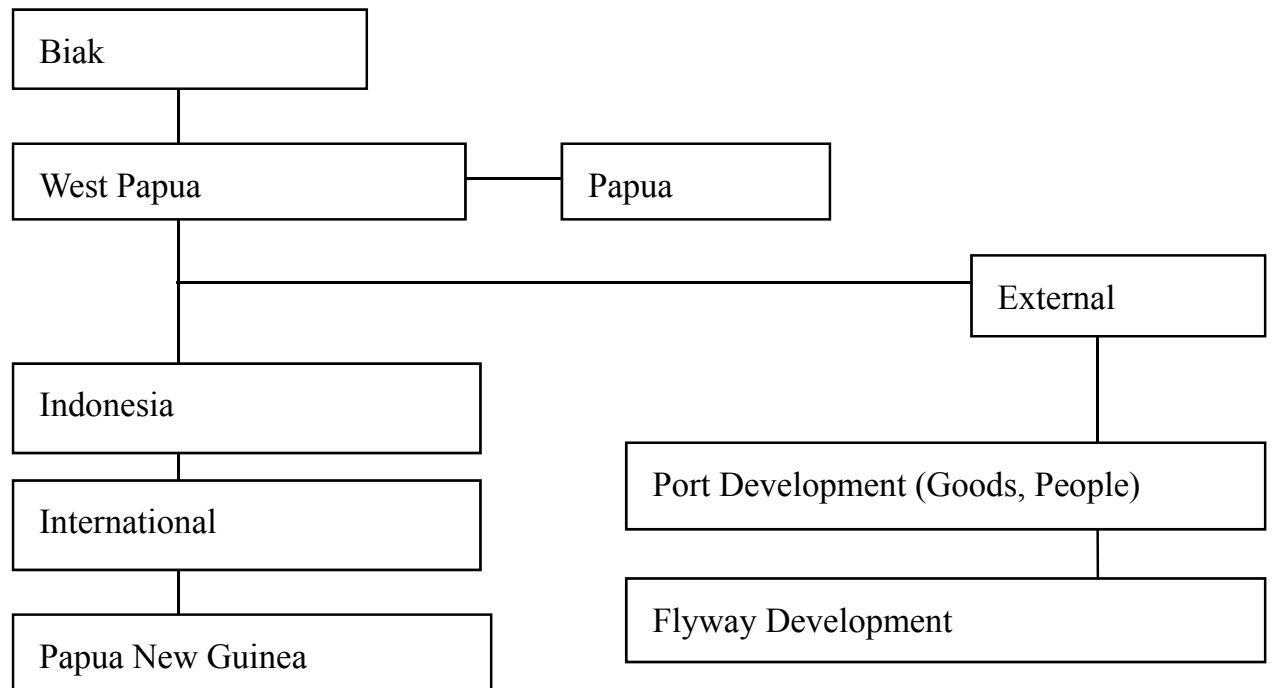

Figure 7. The relationship of Papua and other provinces and international

\section{Perception of Culture}

Indigenous Papuans' perceptions of the concept of Papua's planned development, designed and implemented within the framework of the Republic of Indonesia are difficult to explain and predict within the usual academic framework and formal framework of thinking.

The way to think about mutual benefits and benefits for the broader interests of a single country can not be equated with other people's thinking in the territory of the Republic of Indonesia. However, the concept of thinking about the benefits of money for personal interests, family, or family groups, it can be said to be smart from the point of view of self-interest.

Agrarian law and land ownership that has been successfully implemented in other regions of the Unitary State of the Republic of Indonesia in almost 7 (seven) decades, has not much result applied in this region.

The above has been a major difficulty in bringing down the technical team for infrastructure development, since the topographic teams for design and design interests, until the construction team to realize the planned and designed buildings.

From the data obtained from engineers and assistant engineers who have experienced in the field in this region, general conclusion that the local community many apply unusual money collection.

Awareness to assist development programs for the common good, is still very low in the community of this region in rural areas. In urban areas it is better, because it has been assimilated to the migrant population and many indigenous people have been educated within the framework of national education programs and concepts.

It is still an issue to answer the question of whether in later generations the region's developmental obstacles in terms of culture will be slowly resolved through national education, or still today. Because of course education is not only a formal education in school, but also outside the official school.

It is not easy to continue and finalize the discussion and analysis of the cultural side of the people of this region in its perception of its development within the framework of Indonesia's national program. But it needs to continue to be done equity even in the context of the Papuans as citizens of the world, to accelerate their welfare and increase the quality of hisupnya within the framework of the prevalent criteria of the world community. The deep within the framework of the prevailing world community criteria needs to be continuously dieleminir in the future, as a shared responsibility.

\section{Conclusions and Recommendations}

1) Development in Papua, Indonesia requires acceleration. The underdevelopment of development outcomes in Papua can be seen in comparison with other provinces in Indonesia, especially in terms of the abundance of natural potential and unprocessed land potential.

2) The small number of Papuans is one of the obstacles in the process of proposing development funds that 
require a feasibility study on economic and financial aspects. Therefore, special frameworks and criteria are needed to enable development funds to be used to accelerate development in Papua, Indonesia.

3) Acceleration of development in Papua, Indonesia will be highly dependent in parallel with the construction of its infrastructure system. The construction of a cement plant in Papua, Indonesia which is supported by the development of electrical resources can accelerate and facilitate the development and development of road networks of rigid pavement.

4) To access the central part of Papua from the south coast, it is necessary to develop river transportation, in the form of dock construction and operation of suitable boats of type and type.

5) Cultural transformation is needed, for the new generation of Papua so that it is no longer found or faced by the culture and point of view of the Indonesian people of Papua that is not or is in line with the vision of the development of the Republic of Indonesia and the universal point of view of universal humanity.

\section{References}

Area of provinces of Indonesia. (2016). Retrieved from https://www.bps.go.id/statictable/2014/09/05/1366/luas-daerah-dan-jumlah-pulau-menurut-provinsi-2002-2 016.html

Demography of Australia. Retrieved from https://en.wikipedia.org/wiki/Demography_of_Australia

Demography of Indonesia. Retrieved from https://en.wikipedia.org/wiki/Indonesia

Demography of Papua New Guinea. Retrieved from https://en.wikipedia.org/wiki/Papua_New_Guinea

Demography of Philippines. Retrieved from https://en.wikipedia.org/wiki/Philippines

$\begin{array}{lllll}\text { Population } & \text { of } & \text { Australia. } & \text { (2018). } & \text { Retrieved }\end{array}$ http://www.worldometers.info/world-population/australia-population/

Population of Papua New Guinea. (2018). Retrieved from http://www.worldometers.info/world-population/papua-new-guinea-population/

Population of Philiphines. (2018). from http://www.worldometers.info/world-population/philiphines-population/

Population of provinces in Indonesia. (2010). Retrieved from https://www.bps.go.id/statictable/2009/02/20/1267/penduduk-indonesia-menurut-provinsi-1971-1980-19901995-2000-dan-2010.html

Various Potential Maps of Papua, Indonesia. Retrieved from https://papua.go.id/

\section{Copyrights}

Copyright for this article is retained by the author(s), with first publication rights granted to the journal.

This is an open-access article distributed under the terms and conditions of the Creative Commons Attribution license (http://creativecommons.org/licenses/by/4.0/). 